\title{
Юрій М. Сафонов ${ }^{1}$, Вікторія I. Борщ ${ }^{2}$ \\ СТРАТЕГІЧНИЙ МЕНЕДЖМЕНТ ЗАКЛАДІВ ОХОРОНИ ЗДОРОВ'Я: ЗАГАЛЬНІ ПРИНЦИПИ ТА ОСОБЛИВОСТІ ЗАСТОСУВАННЯ В ГАЛУЗІ ОХОРОНИ ЗДОРОВ'Я УКРАЇНИ
}

Наразі національна галузь охорони здоров'я потребує значних змін у системі ї̈ управління, а також в управлінні закладами охорони здоров'я. Удосконалення процесу стратегічного управління с одним із найбільи дієвих засобів, що покликані підвищити ефективність управління сучасними закладами охорони здоров'я Украӥни. Отже, метою цвого дослідження є визначення фундаментальних принципів впровадження стратегічного менеджменту в закладах охорони здоров'я Украӥни враховуючи міжнародний досвід та практику. Основними методами, які були використані в дослідженні, є синтез та аналіз даних, узагальнення та порівняння. Об'єктом дослідження є галузь охорони здоров'я Украӥни. Практичне значення результатів наукових досліджень полягає у визначенні загальних принципів стратегічного менеджменту закладів охорони здоров'я, що є важкливим для підвищення ефективності діяльності закладів охорони здоров'я в Украӥні. У статті наводяться чинники, що впливають на діяльність сучасних закладів охорони здоров'я. Аргументовано, що стратегічний менеджмент $\epsilon$ інструментом впливу на ці иинники. Доведено, що стратегічне мислення є необхідною умовою керівника закладу охорони здоров'я, оскільки він є інтелектуальним та інноваційним лідером усіх змін, що відбуваються в закладах охорони здоров'я. Зроблено висновок про те, що потреба в застосуванні стратегічного менеджменту в діяльності медичних закладів є досить високою, проте існує низка иинників, які ускладнюють цей процес, а саме некомпетентність керівних кадрів, обмежсність фінансових та організаційних ресурсів, відсутність мотивації до розвитку тощо. Отже, автором зазначено необхідність створення відповідних умов для реалізації стратегічної функції менеджменту, що має бути забезпечена формуванням та розвитком управлінського капіталу закладів охорони здоров'я.

Ключові слова: стратегічний менеджмент; медичний менеджмент; стратегічне мислення; управлінський капітал; охорона здоров'я; заклад охорони здоров'я; управління закладом охорони здоров'я.

Puc. 2. Jim. 14.

ДОІ 10.32752/1993-6788-2019-1-218-62-69

Юрий Н. Сафонов, Виктория И. Борщ

\section{СТРАТЕГИЧЕСКИЙ МЕНЕДЖМЕНТ УЧРЕЖДЕНИЙ ЗДРАВООХРАНЕНИЯ: ОСНОВНЫЕ ПРИНЦИПЫ И ОСОБЕННОСТИ ПРИМЕНЕНИЯ В ОТРАСЛИ ЗДРАВООХРАНЕНИЯ УКРАИНЫ}

Современная национальная отрасль здравоохранения требует значительных изменений в системе ее управления, а также в управлении учреждениями здравооранения. Совершенствование процесса стратегического управления является одним из самых действенных средств, которые призваны повысить эффективность управления современными учреждениями здравоорранения Украины. Итак, целью данного исследования является определение фундаментальных принципов внедрения стратегического менеджмента в учреждениях здравооранения Украины учитывая международный опыт и практику. Основными методами, которые были использованы в исследовании, являются синтез и анализ данных, обобщение и сравнение. Объектом

\footnotetext{
${ }_{2}^{1}$ Kyiv National Economic University named after Vadym Hetman. Kyiv.

2 Odessa I. I. Mechnikov national university. Odessa. Ukraine.
}

(C) Yurii M. Safonov, Viktoriia I. Borshch, 2019 
исследования является отрасль здравоохранения Украины. Практическое значение результатов научных исследований заключается в определении общих принципов стратегического менеджмента учреждений здравоохранения, ито является важным для повышения эффективности деятельности учреждений здравоохранения в Украине. В статье представлены факторы, влияющие на деятельность современных учреждений здравоохранения. Аргументировано, что стратегический менеджмент является инструментом воздействия на эти факторы. Доказано, что стратегическое мышление является необходимым условием руководителя учреждения здравоохранения, поскольку он является интеллектуальным и инновационным лидером всех изменений, происходящих в учреждениях здравоохранения. Сделан вывод о том, что потребность в применении стратегического менеджмента в деятельности медицинских учреждений является достаточно высокой, однако существует ряд факторов, которые усложняют этот процесс, а именно некомпетентность руководящих кадров, ограниченность финансовых и организационных ресурсов, отсутствие мотивации к развитию и т.д. Итак, автором отмечено необходимость создания соответствующих условий для реализации стратегической функции менеджмента, ито должно быть обеспечено формированием и развитием управленческого капитала учреждений здравоохранения.

Ключевые слова: стратегический менеджмент; медииинский менеджмент; стратегическое мышление; управленческий капитал; здравоохранение; учреждение здравоохранения; управление учреждением здравоохранения.

Yurii M. Safonov, Viktoriia I. Borshch

\section{BASIC PRINCIPLES AND FEATURES OF HEALTHCARE STRATEGIC MANAGEMENT: A CASE OF UKRAINIAN HEALTH CARE}

Nowadays, the national health sector needs significant changes in its management system, as well as in the management of healthcare facilities. Improving the strategic management process is one of the most viable means to increase management efficiency of modern healthcare institutions in Ukraine. Therefore, the purpose of this study is to determine the fundamental principles of implementing strategic management in Ukrainian healthcare institutions, taking into account international experience and practice. The main methods used in this study are synthesis and analysis of data, generalization and comparison. The object of research is Ukrainian healthcare sector. The practical value of scientific research results is to determine the general principles of strategic management at healthcare institutions, which is important for improving the efficiency of healthcare facilities in Ukraine. The article provides the factors influencing the activity of modern healthcare institutions. It is argued that strategic management is an instrument for influencing these factors. It is proved that strategic thinking is a prerequisite for the healthcare provider, as he is an intellectual and innovative leader in all the changes taking place in healthcare facility. It is concluded that the need to apply strategic management in the activities of medical institutions is rather high, but there are a number of factors that complicate this process, namely, the incompetence of management personnel, limited financial and organizational resources, lack of motivation for development, etc. Thus, the author pointed out the need to create the appropriate conditions for the implementing strategic management, which should be ensured by the formation and development of managerial capital of health facilities.

Keywords: strategic management; health management; strategic thinking; managerial capital; health care; healthcare facility; healthcare facilities management.

Peer-reviewed, approved and placed: 18.08.2019.

Постановка проблеми. В останні роки реформування національної системи охорони здоров'я та зміни у світовій системі, що, передусім, пов'язані 
iз фінансуванням, розвитком приватного сектору охорони здоров'я, підвищенням рівня конкуренції на ринку медичних послуг та пошуком нових шляхів підвищення ефективності та результативності закладів охорони здоров'я, призвели до нових викликів для цих закладів та їхніх керівників. Основним таким викликом є те, що спочатку XXI століття із демографічним зростанням росте попит на медичні послуги та виникає потреба в реструктуризації діяльності медичних закладів та формуванні більш розвиненої медичної інфраструктури. Це призводить до того, що виникає потреба в комплексному оновленні медичного менеджменту.

Заклади охорони здоров’я працюють як у державному, так і в приватному секторі, отже, незважаючи на соціальну місію, що має на меті покращення стану здоров'я громадян України, вони мають дотримуватися принципу економічної доцільності та ефективності діяльності. Отже, постає проблема успішного управління цими закладами, що потребує застосування принципів стратегічного менеджменту: з одного боку, вони мають формувати успішні бізнес моделі, а з іншого - належним чином реалізовувати їх завдяки стратегії.

Аналіз останніх досліджень і публікацій. Проблема імплементації принципів та інструментів стратегічного менеджменту в практиці управління закладами охорони здоров'я є дуже актуальною як для вітчизняних, так і світових науковців.

Цікавими є наукові позиції І. М. Шохета (Ізраїль) [10; 11] та Ф. Насірі та О. Моселхі (Канада) [14], які вивчають роль стратегічного менеджменту в управлінні об’єктами. Наукові дослідження Дж. Сеціале (Італія) [13] спрямовані на аналіз впливу стратегічного менеджменту на ефективність закладів охорони здоров’я та ефективність клінічної діяльності цих закладів. Л.Е. Свейн, У.Дж. Дункан та П.М. Джінтер у [13] розглядають фундаментальні засади стратегічного менеджменту в закладах охорони здоров’я США.

Актуальними для нашого дослідження $є$ наукові доробки російських науковців: Л.С. Гринкевича та А.С. Баніна [2], О.А. Латухи [3], В.М. Лимаренко [4] та Н.А. Кузнецової [5].

Українські науковці також присвятили свої наукові дослідження цьому питанню. Особливої уваги слід приділити науковим публікаціям Ю.В. Вороненка [1], Л.С. Стефанишина [6], В.Д. Чопчика та Н.М. Орлової [8] тощо.

Проте незважаючи на значну кількість наукових доробок, перед сучасним керівництвом закладів охорони здоров'я України, особливо державного сектору, постає проблема практичного використання принципів менеджменту в управлінні цими закладами з метою підвищення їхньої ефективності.

Метою дослідження $€$ визначення фундаментальних принципів впровадження стратегічного менеджменту в закладах охорони здоров'я України враховуючи міжнародний досвід та практику.

Основні результати дослідження. Перенесення принципів менеджменту від комерційних підприємств приватного сектору економіки до некомерційних, а в нашому випадку - до закладів охорони здоров'я, має тривалу історію, починаючи з XX століття. Усе розпочалося з пропаганди використання принципів менеджменту в закладах охорони здоров'я, а наразі ще тривають процеси впровадження практики стратегічного менеджменту, менеджменту 
якості (Total quality management - TQM), управління об'єктами (maintenance management) та управління показниками діяльності (performance management). Незважаючи на те, що методи та підходи до менеджменту змінюються, проте їхня імплементація в практику управління медичними закладами спрямована на підвищення якості та ефективності управлінського процесу, а навіть інколи й на забезпечення виживання цих закладів.

Сьогодні в галузі охорони здоров'я України відбуваються значні трансформації, які ознаменувалися переходом до нової моделі фінансування закладів, їхньої автономізації, а отже, й пошуком нових механізмів управління. У результаті, як приватні, так і державні медичні заклади діють в умовах зовнішнього середовища, що швидко змінюється та на яке впливає багато чинників (інституційні, правові, економічні, демографічні, технікотехнологічні тощо) (рис. 1).

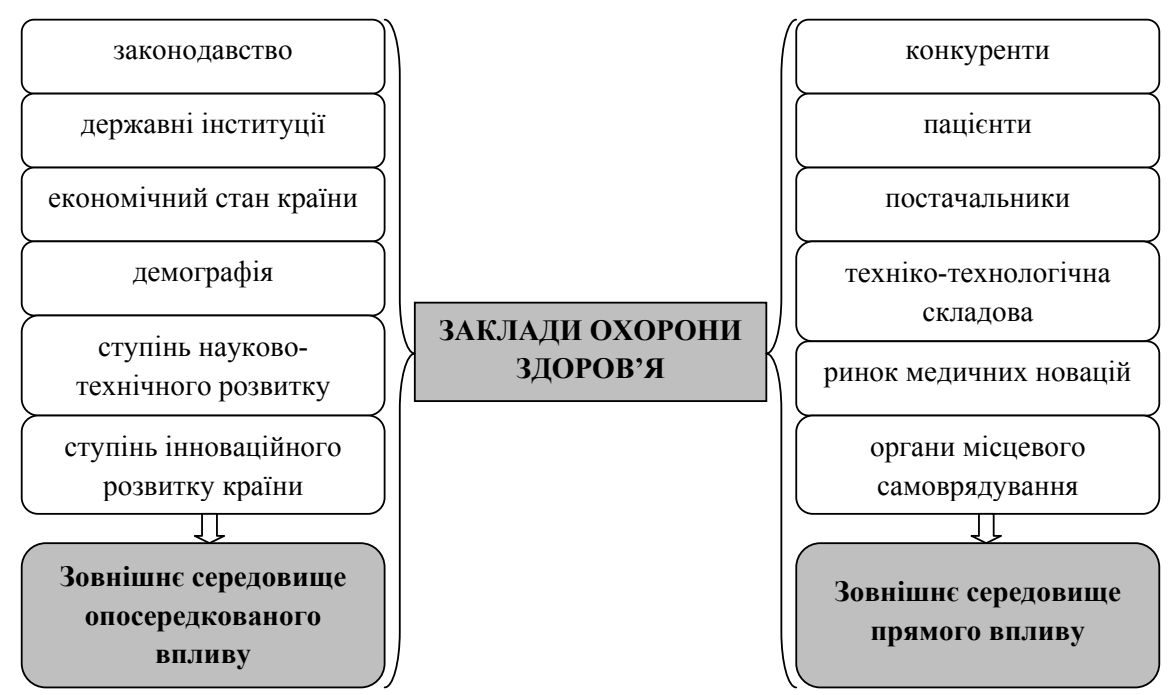

Рис. 1. Чинники зовнішнього середовища, що впливають на діяльність закладів охорони здоров'я, розроблено автором

Зовнішнє середовище національних закладів охорони здоров'я характеризується інтеграційними процесами, залежністю від світового господарства, посиленням тиску світового ринку медичних послуг та фармацевтичного ринку, відсутністю систематизованих орієнтирів для вибору напрямів розвитку, недостатністю або повною відсутністю стратегічної інформації [4].

Отже, система медичного менеджменту має бути скерована на адаптацію закладів охорони здоров'я до цих чинників, а також на управління ними, що $є$ однією з основних функціональних сфер впливу стратегічного менеджменту.

Стратегічний менеджмент представляє собою «імпульс» для динамічних змін закладу охорони здоров'я [13, с. 7]. Стратегічний менеджмент - це активний процес, що дає змогу стратегічним планам розвиватися і формуватися зі змінами середовища. Отже, виникає потреба в проактивній стратегії, яка 
спрямована на (1) максимізацію цінності медичної послуги для пацієнтів шляхом отримання найкращих результатів за найменших витратах; та (2) перехід від лікувального процесу до управління медичним закладом та його клінічними та іншими процесами.

Проте комплексні системи, як правило, дуже консервативні та чинять опір змінам; система охорони здоров'я не є винятком. Ще одним викликом $є$ те, що лікарі є центральними «гравцями» в еволюції системи охорони здоров'я та іiі закладів, а отже, стратегія, яку вони не підтримують, зазнає краху. Основною вимогою впровадження стратегічного менеджменту в закладах охорони здоров'я є залучення вищого лікарського складу до трансформації системи менеджменту 3 зосередженням уваги на спільній меті та застосуванням якісного механізму їхньої мотивації та стимулювання [12]. Відповідно, ефективний процес формування та реалізації стратегії вимагає каскадного підходу, що направлено на забезпечення єдності та підпорядкованості, з одного боку, стратегічних, оперативних і тактичних цілей, а з іншого - інтересів керівників, структурних підрозділів та персоналу для досягнення загально організаційної мети закладу.

Впровадження принципів стратегічного менеджменту в практику управління закладами охорони здоров'я передбачає:

1. Впровадження організаційних змін: зменшення жорсткості та ієрархічності структур управління, розвиток програмно-цільового управління, гнучкість організаційної структури (увага до автономізації діяльності, делегуванню повноважень, командної роботи та проектного менеджменту).

2. Зосередження уваги на координаційній функції менеджменту, що пов'язана із прогнозуванням проблем, процесом прийняття управлінських рішень, координацією робіт із забезпеченням взаємодії між різними структурними підрозділами - усередині та медичним закладом і афілійованими особами - ззовні, стимулюванням діяльності.

3. Імплементація механізмів управління ризиками та ризик-менеджменту.

4. Управління інноваціями та стимулювання інноваційної діяльності закладів охорони здоров'я із наданням індивідуальної ініціативи та розвитком лідерських якостей.

5. Стимулювання постійного процесу розвитку персоналу медичного закладу та перехід до моделі самоосвітньої організації.

6. Зосередження уваги на підвищення якості всіх видів діяльності закладу, а також його ефективності із забезпеченням формування та розвитку культури результативності медичного закладу.

7. Тенденція до підвищення ролі та значення організаційної культури закладу охорони здоров'я із залученням персоналу до формування стратегії розвитку, управління закладом, формування нової якості медичної послуги тощо.

8. Спрямування операційної діяльності закладу охорони здоров'я на створення медичної послуги більш високої якості чи з новими властивостями за умови зменшення іiї собівартості.

9. Запровадження принципів інтелектуального та інноваційного лідерства, що базується на розвитку емоційного та практичного інтелекту в 
працівників, компетентнісному підході, критичному мисленні, креативному менеджменті.

10. Формування управлінського капіталу, що забезпечує ефективність системи управління закладом охорони здоров'я.

Отже, сучасний менеджмент медичного закладу має орієнтуватися не лише на застосуванні принципів та інструментів стратегічного менеджменту, проте має зосереджуватися на культивуванні у своїх управлінців стратегічного мислення. Стратегічне мислення - це «особливий тип системного мислення, який об'єднує раціональний і творчий компоненти, об’єктивний і суб’єктивний аспекти, ... інтегрує різноманітні концепції й методи в складному процесі стратегічної діяльності» [7]. На думку 3. Є. Шершньової, стратегічне мислення «полягає в усвідомленні мети розвитку підприємства та способів іiі досягнення, у ствердженні необхідності спостереження за зовнішнім і внутрішнім середовищами (для визначення мети та способів досягнення), формування стратегій та рішень, що з них випливають, а також налагодження діяльності 3 метою їх здійснення. Стратегічне мислення передбачає: усвідомлення управлінської ієрархії та послідовності встановлення пріоритетів; орієнтацію на розпізнавання та адекватне реагування на зміни в середовищі - нові можливості та потенційні загрози; усвідомлення можливостей та масштабів впливу на формування середовища, а не лише реагування на зміни» [9].

Модель стратегічного мисленням, що передбачає аналітичну і проактивну систему поглядів стратегічного менеджменту, а також ілюструє взаємозв'язок між основними компонентами стратегічного менеджменту, представлено на рис. 2.

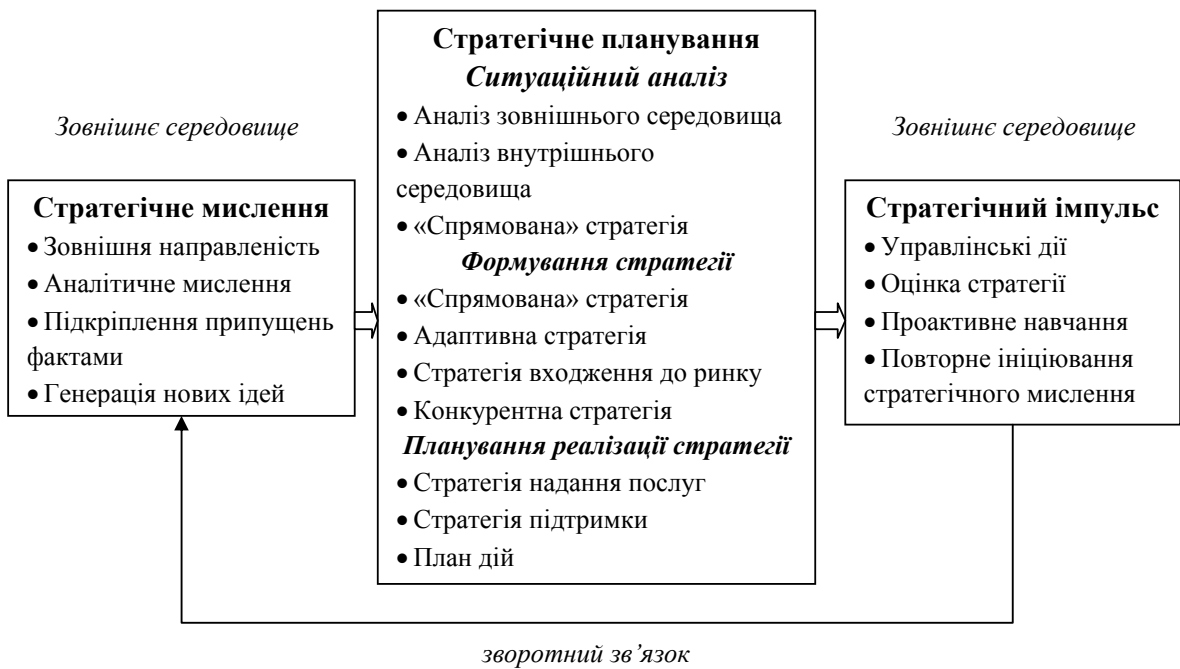

Рис. 2. Модель стратегічного мислення в процесі стратегічного менеджменту, адаптовано [13, с. 18]

Представлена на рис. 2, модель стратегічного мислення має стати основою для менеджерів закладів охорони здоров'я в процесі стратегічного 
планування та реалізації стратегії. Як ми бачимо, менеджери мають стати стратегічними мислителями, які здатні оцінювати зміни в зовнішньому середовищі, аналізувати інформацію, робити гіпотези та генерувати нові ідеї. Також вони мають формувати план дій для стратегічного планування, що складається з трьох етапів: 1) ситуаційний аналіз; 2) формування стратегії; та 3) реалізація стратегії. Стратегічне планування - це процес прийняття управлінських рішень, як структурованих, так і неструктурованих. Після розробки стратегії менеджери повинні управляти «стратегічним імпульсом» закладу: оцінювати його результат, аналізувати позитивні сторони та недоліки та стимулювати нове стратегічне мислення [13, с. 18].

Потреба в стратегічному мисленні в рамках управління закладами охорони здоров'я є високою, проте його розвиток ускладнюється такими причинами:

1) недостатнім рівнем компетентності управлінських кадрів закладів охорони здоров'я;

2) відсутністю спеціальної освіти у сфері управління в керівників закладів охорони здоров'я;

3) небажанням управлінських кадрів та персоналу розвиватися та запроваджувати нові технології управління;

4) обмеженість фінансових ресурсів;

5) обмеженість організаційних ресурсів;

6) нерозвиненість корпоративної культури закладів охорони здоров'я (особливо це стосується державного сектору);

7) стагнацією галузі охорони здоров’я України.

Висновки. Поява ефективних інноваційних, стратегічно активних закладів охорони здоров’я та підвищення рівня конкуренції на ринку медичних послуг призводить до необхідності розвитку механізмів застосування стратегічного менеджменту в управлінні цими закладами, а також до посилення ролі керівника медичного закладу як стратега й новатора. Сьогодні заклади охорони здоров’я працюють в умовах постійних динамічних змін. Так, керівникам необхідно впоратися з цими бурхливими змінами та зробити так, щоби заклади отримали конкурентні переваги від цих змін, уникаючи нових загроз. Сучасні керівники потребують нового типу мислення - проактивного та критичного, що і є стратегічним мисленням.

Отже, сучасний медичний менеджмент потребує розробки науково обгрунтованої стратегії управління та розвитку закладами охорони здоров'я. Освоєння інструментів та методів стратегічного управління закладами охорони здоров'я на основі створення та розвитку відповідної наукової теоретико-методологічної бази, яка враховує специфіку галузі охорони здоров’я, є необхідною умовою подальшого реформування національної сфери охорони здоров’я та формування державної політики в цій галузі.

1. Вороненко Ю.В. Стратегічне управління в охороні здоров'я: теоретичні та практичні аспекти. Науковий журнал МОЗ України. 2014. № 1 (5). С. 39-46.

Voronenko $\mathrm{Yu}$. V. Stratehichne upravlinnia v okhoroni zdorovia: teoretychni ta praktychni aspekty. Naukovyi zhurnal MOZ Ukrainy. 2014. № 1 (5). S. 39-46. 
2. Гринкевич Л.С., Банин А.С. Совершенствование методов управления учреждениями здравоохранения в России. Вестник Томского государственного университета. 2006. С. 105-113. URL: sun.tsu.ru/mminfo/000063105/292/image/292_105-113.pdf

Grinkevich L.S., Banin A.S. Sovershenstvovanie metodov upravleniya uchrezhdeniyami zdravookhraneniya v Rossii. Vestnik Tomskogo gosudarstvennogo universiteta. 2006. S. 105-113. URL: sun.tsu.ru/mminfo/000063105/292/image/292_105-113.pdf

3. Латуха O.A. Стратегия как ключевой фактор успеха работы медицинской организации. Вестник Новосибирского государственного педагогического университета. 2016. 1 (29). С. 149256. DOI: $10.15293 / 2226-3365.1601 .14$

Latukha O.A. Strategiya kak klyuchevoy faktor uspekha raboty meditsinskoy organizatsii. Vestnik Novosibirskogo gosudarstvennogo pedagogicheskogo universiteta. 2016. 1 (29). S. 149-256. DOI: $10.15293 / 2226-3365.1601 .14$

4. Лымаренко В.М. Факторы, обсуславливающие необходимость применения стратегического управления в деятельности поликлинических учреждений здравоохранения. 2016. URL: https://docplayer.ru/87354470-Ano-vpo-universitet-pri-mezhparlamentskoy-assamblee-evraziyskogoekonomicheskogo-soobshchestva-lymarenko-valeriy-mihaylovich.html

Lymarenko V.M. Faktory, obsuslavlivayushchie neobkhodimost' primeneniya strategicheskogo upravleniya v deyatel'nosti poliklinicheskikh uchrezhdeniy zdravookhraneniya. 2016. URL: https://docplayer.ru/87354470-Ano-vpo-universitet-pri-mezhparlamentskoy-assamblee-evraziyskogo-ekonomicheskogo-soobshchestva-lymarenko-valeriy-mihaylovich.html

5. Кузнецова Н.A., Трескова М.В. Стратегическое планирование в системе управления учреждения здравоохранения. Вектор экономики. 2017. № 11 (17). С. 69-71.

Kuznetsova N. A., Treskova M. V. Strategicheskoe planirovanie v sisteme upravleniya uchrezhdeniya zdravookhraneniya. Vektor ekonomiki. 2017. № 11 (17). S. 69-71.

6. Стефанишин Л.С. Теоретико-методичні основи стратегічного управління закладом охорони здоров’я. Інфраструктура ринку. 2019. Вип. 30. С. 77-83.

Stefanyshyn L.S. Teoretyko-metodychni osnovy stratehichnoho upravlinnia zakladom okhorony zdorovia. Infrastruktura rynku. 2019. Vyp. 30. S. 77-83.

7. Тригобюк С.С. Стратегічне мислення як основа сучасного стратегічного планування. Вісник Національного університету "Львівська політехніка". 2008. № 633. С. 718-720.

Tryhobiuk S. S. Stratehichne myslennia yak osnova suchasnoho stratehichnoho planuvannia. Visnyk Natsionalnoho universytetu "Lvivska politekhnika". 2008. № 633. S. 718-720.

8. Чопчик В.Д., Орлова Н.М. Стратегічне планування бізнес-діяльності стоматологічного центру, основаного на засадах державно-приватного партнерства. Вісник соціальної гігієни та організації охорони здоров’я України. 2018. № 4 (78). С. 26-31

Chopchyk V. D., Orlova N. M. Stratehichne planuvannia biznes-diialnosti stomatolohichnoho tsentru, osnovanoho na zasadakh derzhavno-pryvatnoho partnerstva. Visnyk sotsialnoi hihiieny ta orhanizatsii okhorony zdorovia Ukrainy. 2018. № 4 (78). S. 26-31

9. Шериньова 3. С., Оборська С. В., Ратушний Ю. М. Стратегічне управління : Навч.-метод. посібник. Київ : КНЕУ, 2001. 232 с.

Shershnova Z. Ye., Oborska S. V., Ratushnyi Yu. M. Stratehichne upravlinnia : Navch.-metod. posibnyk. Kyiv : KNEU, 2001. 232 c.

10. Shohet I.M. Key performance indicators for maintenance of healthcare buildings. Facilities. 2003. 21 (1/2). Pp. 5-12.

11. Shohet I.M. Key parameters for strategic healthcare facilities management. Journal of Construction Engineering and Management. April 2006132 (4). DOI: 10.1061/(ASCE)07339364(2006)132:4(345)

12. Speziale $G$. Strategic management of a healthcare organization: engagement, behavioural indicators, and clinical performance. European Heart Journal Supplements. 2015. 17. A3-A7. doi:10.1093/eurheartj/suv003

13. Swayne L. E., Duncan W. J., Ginter P. M. Strategic management of health care organizations. 5th ed. Blackwell Publishing. 2006. 888 p.

14. Zahra Yousefli, Fuzhan Nasiri, Osama Moselhi. Healthcare facilities maintenance management: a literature review. Journal of Facilities Management. July 2017. Pp. 1-24. DOI: 10.1108/JFM-10-20160040 